\title{
Induction of apoptosis and cell cycle arrest by NS398 in oral squamous cell carcinoma cells via downregulation of $\mathrm{E} 2$ promoter-binding factor-1
}

\author{
YIFEI DU ${ }^{1,2}$, SHUANGYUE ZHANG ${ }^{1,2}$, ZILU WANG ${ }^{2}$, WEINA ZHOU ${ }^{2}$, \\ MINGLIANG LUAN ${ }^{1,2}$, XIAOHAN YANG ${ }^{1,2}$ and NING CHEN ${ }^{1,2}$ \\ ${ }^{1}$ Department of Oral and Maxillofacial Surgery, School of Stomatology; ${ }^{2}$ Institute of Dental Research, \\ Nanjing Medical University, Nanjing 210029, P.R. China
}

Received March 28, 2008; Accepted May 6, 2008

DOI: 10.3892/or_00000048

\begin{abstract}
Overexpression of cyclooxygenase-2 (COX-2) plays an important role in development and progression of different human cancers, but the underlying molecular mechanisms remain to be defined. Tissue specimens of normal oral epithelia $(n=9)$, dysplasia $(n=38)$, and oral squamous cell carcinoma ( $\mathrm{SCC}, \mathrm{n}=54$ ) were immunohistochemically analyzed for COX-2 and E2F-1 expression. A human oral SCC cell line, Tca8113, was used to assess NS398 antitumor activity. $\mathrm{PGE}_{2}$ levels were measured by using radioimmunoassay, and COX-2, pRb, and E2F-1 proteins were determined by Western blot assay. We found expression of COX-2 and E2F-1 proteins was significantly increased in both oral dysplasia and SCC compared to the normal epithelium. Increased COX-2 expression was associated with E2F-1 expression in both oral dysplasia and SCC. NS398 treatment reduced viability of Tca8113 cells in a dose- and time-dependent manner. NS398 suppressed PGE $_{2}$ levels, a product of COX-2 enzyme, in the tumor cells. The reduced cell viability is due to induction of apoptosis by NS398, which activates caspase-3, but does not inhibit bcl-2. NS398 also induced tumor cell arrest at G1 phase of the cell cycle and inhibited expression of $\mathrm{COX}-2, \mathrm{pRb}$ and E2F-1 proteins. This study provides evidence that E2F-1 and COX-2 are overexpressed in oral cancer, and further supports suppression of COX-2 in control of oral cancer.
\end{abstract}

\section{Introduction}

Oral squamous cell carcinoma (SCC) is one of the most common malignancies in the world, with high incidence and

Correspondence to: Dr Ning Chen, Department of Oral and Maxillofacial Surgery, School of Stomatology, Nanjing Medical University, Nanjing 210029, P.R. China

E-mail: njen@njmu.edu.cn

Key words: COX-2, E2F-1, oral cancer, apoptosis, immuohistochemistry mortality rate in the Asian oral cancer belt $(1,2)$. Tobacco smoke and alcohol consumption are significant risk factors for oral squamous cell carcinoma, and chronic irritants such as mouthwash and poor dental hygiene have also been considered as etiological factors. Despite advancement in various treatment modalities, including surgical intervention, radiotherapy and chemotherapy, the survival rate of patients with oral SCC has not been significantly improved $(1,2)$ Therefore, more effective approaches for prevention and treatment are urgently needed.

Cyclooxygenase-2 (COX-2), a rate-limiting enzyme in the prostaglandin synthesis pathway, is one of the important cellular factors in promoting cancer development and progression. Indeed, epidemiological and experimental studies have demonstrated increased expression of COX-2 enzyme in cancers of the colon, stomach, breast, esophagus, lung, pancreas and brain (3-9). The effectiveness of non-steroidal anti-inflammatory drugs (NSAIDs) in prevention of human cancers, including oral SCC, has been proven in vitro and in vivo (10-13). However, the underlying molecular mechanisms by which NSAIDs prevent human cancer are not well defined.

Many studies have shown that NSAIDs have the ability to alter cell cycle kinetics in a number of human tumor cells, and cell cycle alteration seems to be a major contributing factor in NSAID-mediated cancer toxicity $(14,15)$. This implies that the actual mechanism underlying the antiproliferative activity of NSAIDs may be related to some cellular factors involved in cell cycle inhibition. E2 promoterbinding factor-1 (E2F-1), was the first cloned and is the best characterized member of this gene family $(16,17)$. E2F-1 plays a pivotal role in regulating the expression of genes involved in the G1-S transition and DNA synthesis (18), and is the most well-known transcription factor regulated by the cyclin/Cdk/Rb pathway. Several lines of evidence indicate that E2F-1 is involved in neoplastic development. Recent studies showed that deregulation of the $\mathrm{Rb} / \mathrm{E} 2 \mathrm{~F}$ complex results in increased COX-2 expression and activity in prostate epithelial cells (19), and that celecoxib, a COX-2-selective inhibitor, profoundly inhibits nuclear E2F function in head and neck squamous cell carcinoma, leading to G1 phase accumulation (20). These findings indicated a correlation 
between NSAID-induced cell cycle inhibition and the Rb/ E2F pathway. However, very few studies have confirmed these mechanistic patterns in various tumor cells. In this study, we detected COX-2 and E2F-1 expression in tissue specimens of normal oral epithelia, dysplasia, and SCC in a Chinese patient population. We then assessed anti-proliferation activity and cell cycle inhibition by NS398, a COX-2selective inhibitor, in a human oral SCC cell line Tca8113 and explored the underlying molecular mechanisms.

\section{Materials and methods}

Tissue specimens. Tissue samples used in this study consisted of 38 cases of oral dysplasia and 54 cases of oral SCC, which were collected between January 2002 and December 2004 in the Division of Oral and Maxillofacial Surgery, Stomatological Hospital, Nanjing Medical University. An additional nine cases of normal oral mucosae were obtained from healthy volunteers in the Department of Dental Implant Surgery. All patients signed an informed consent to use their tissue specimens for research.

All specimens were fixed in $10 \%$ buffered formalin and embedded in paraffin. Sections $(3 \mu \mathrm{m})$ were then prepared and pathological diagnoses were made on the basis of hematoxylin and eosin stained sections, according to the WHO classification of oral SCC. Also based on WHO criteria, oral dysplasia was graded into one of three categories: mild, moderate or severe.

Immunohistochemistry. Immunohistochemical staining was performed by using the avidin-biotin-peroxidase technique (ABC). A polyclonal anti-COX-2 antibody (Cat\# sc-1746) and a monoclonal anti-E2F-1 antibody (Cat\# sc-251) were obtained from Santa Cruz Biotechnology, Inc. (Santa Cruz, CA, USA). Briefly, after de-paraffinization and re-hydration, the sections were treated with $3 \%$ hydrogen peroxide for $15 \mathrm{~min}$ to inhibit endogenous peroxidase activity. Antigen retrieval was achieved by using a microwave of the samples in citrate buffer ( $\mathrm{pH}$ 6.0) $(750 \mathrm{~W}$ for 5 min followed by $150 \mathrm{~W}$ for $15 \mathrm{~min}$ ). The sections were then incubated with anti-COX-2 or anti-E2F-1 antibody at a dilution of 1:100 for $1 \mathrm{~h}$ at room temperature and the second antibody was incubated for $1 \mathrm{~h}$, followed by $\mathrm{ABC}$ incubation for $30 \mathrm{~min}$. Immunoreactions were visualized with 3,3-diaminobenzine (DAB) and the sections were counterstained with hematoxylin for $2 \mathrm{~min}$. Some sections were incubated with phosphate buffered saline (PBS) solution instead of the primary antibody as negative controls.

To review and score the stained sections, we selected $>1,000$ cells per section for counting positively stained cells at x40 magnification in five or more microscopic fields. In sections of normal mucosa and oral dysplasia lesions, our counting began at the basal levels of the epithelium and progressed superficially. In oral SCC sections, counting was performed from peripheral to more central regions of the cancer nests.

Positively staining cells were summarized as the labeling index (LI), given as a percentage $(\%)$ of the total cells counted. The data were evaluated semiquantitatively and graded according to the following criteria: low expression, for $<20 \%$ cells stained; and high expression, for $>20 \%(21,22)$. All sections were assessed by two independent researchers experienced in pathologic analysis and immunohistochemistry. If a specimen was found to have differing labeling indices between the two independent readings, a final determination was made by consensus review.

Cell culture. Tca8113, obtained from Institution of Biochemistry and Cell Biology (Shanghai, P.R. China), was cultured in RPMI-1640 medium supplemented with $10 \%$ fetal calf serum, $100 \mathrm{unit} / \mathrm{ml}$ of penicillin and $100 \mu \mathrm{g} / \mathrm{ml}$ of streptomycin under $5 \% \mathrm{CO}_{2}$ at $37^{\circ} \mathrm{C}$.

Cell proliferation assay. A COX-2-selective inhibitor, NS398, was obtained from Cayman Chemical Company (Ann Arbor, MI, USA) and dissolved in dimethylsulfoxide (DMSO) and stored at $-20^{\circ} \mathrm{C}$ as aliquots until use. To assess the effect of NS398 on Tca 8113 cells, the cells $\left(2 \times 10^{4}\right.$ cells/well) were first seeded in 96-well, flat-bottomed plates in triplicate. Different concentrations of NS398 were added in a final volume of $200 \mu \mathrm{l}$ of growth medium/well in the next day. DMSO was added to control wells at equal volumes of the drug. The plates were then incubated at $37^{\circ} \mathrm{C}$ in a $5 \% \mathrm{CO}_{2}$ supplemented atmosphere for 24, 48, 72 and $96 \mathrm{~h}$. At the end of the experiments, the media were removed and replaced by $150 \mu \mathrm{l}$ of $0.5 \mu \mathrm{g} / \mathrm{ml}$ of MTT (Sigma-Aldrich Chemical Co., USA) in the growth medium, and the plates were then incubated for $4 \mathrm{~h}$ at $37^{\circ} \mathrm{C}$. The reduced MTT dye was solubilized with $150 \mu 1 \mathrm{DMSO}$ per well. The optical density (OD) values were read with an ELX800 Universal Microplate reader (Bio-Tek Co., CA, USA) at $570 \mathrm{~nm}$. Percentage of inhibition was calculated as: $\%$ inhibition $=1-($ ODtest $/$ ODcontrol) x $100 \%$.

Flow cytometric analysis. After treatment with NS398 for different periods of time, cell suspensions were prepared by trypsinization and $1 \times 10^{6}$ cells $/ \mathrm{ml}$ were washed with PBS and then fixed overnight in $10 \mathrm{ml}$ of $70 \%$ ethanol $\left(-20^{\circ} \mathrm{C}\right)$ at $4^{\circ} \mathrm{C}$. After that, the cells were incubated with RNase at a concentration of $0.25 \mu \mathrm{g} / \mathrm{ml}$ at $37^{\circ} \mathrm{C}$ for $1 \mathrm{~h}$, then incubated with propidium iodide $(50 \mu \mathrm{g} / \mathrm{ml}$ in PBS $)$ for $30 \mathrm{~min}$ at $4^{\circ} \mathrm{C}$ in the dark. Before flow cytometry analysis, the samples were passed through a 25-gauge needle to prevent nuclear clumps. The samples were incubated in the dark at $37^{\circ} \mathrm{C}$ for $30 \mathrm{~min}$. The cells were then analyzed with a FACSCalibur flow cytometer (Becton-Dickinson, CA, USA). For each sample, 10,000 fluorescent cells were counted. The data were analyzed using ModFit software.

Western blot analysis. After treatment with NS398, the conditioned media were removed and stored at $-70^{\circ} \mathrm{C}$ to assess PGE $_{2}$ levels. Protein lysates from Tca8113 cells were obtained by washing the cells 3 times with ice-cold PBS and scraped in ice-cold lysis buffer (1\% NP-40, $1 \%$ NaTDC, $0.1 \%$ SDS, $0.15 \mathrm{M} \mathrm{NaCl}, 0.01 \mathrm{M} \mathrm{Na}_{3} \mathrm{PO}_{4}, 2 \mathrm{mM}$ EDTA, $50 \mathrm{mM}$ $\mathrm{NaF}$ ). Protein concentrations were determined by using GeneQuant Pro protein assay (GE Healthcare, Piscataway, NJ, USA). Cell extracts (100 $\mu \mathrm{g})$ were separated by electrophoresis on $12 \%$ SDS polyacrylamide gel (PAGE). The protein was then transferred by electroblotting onto a polyvi- 

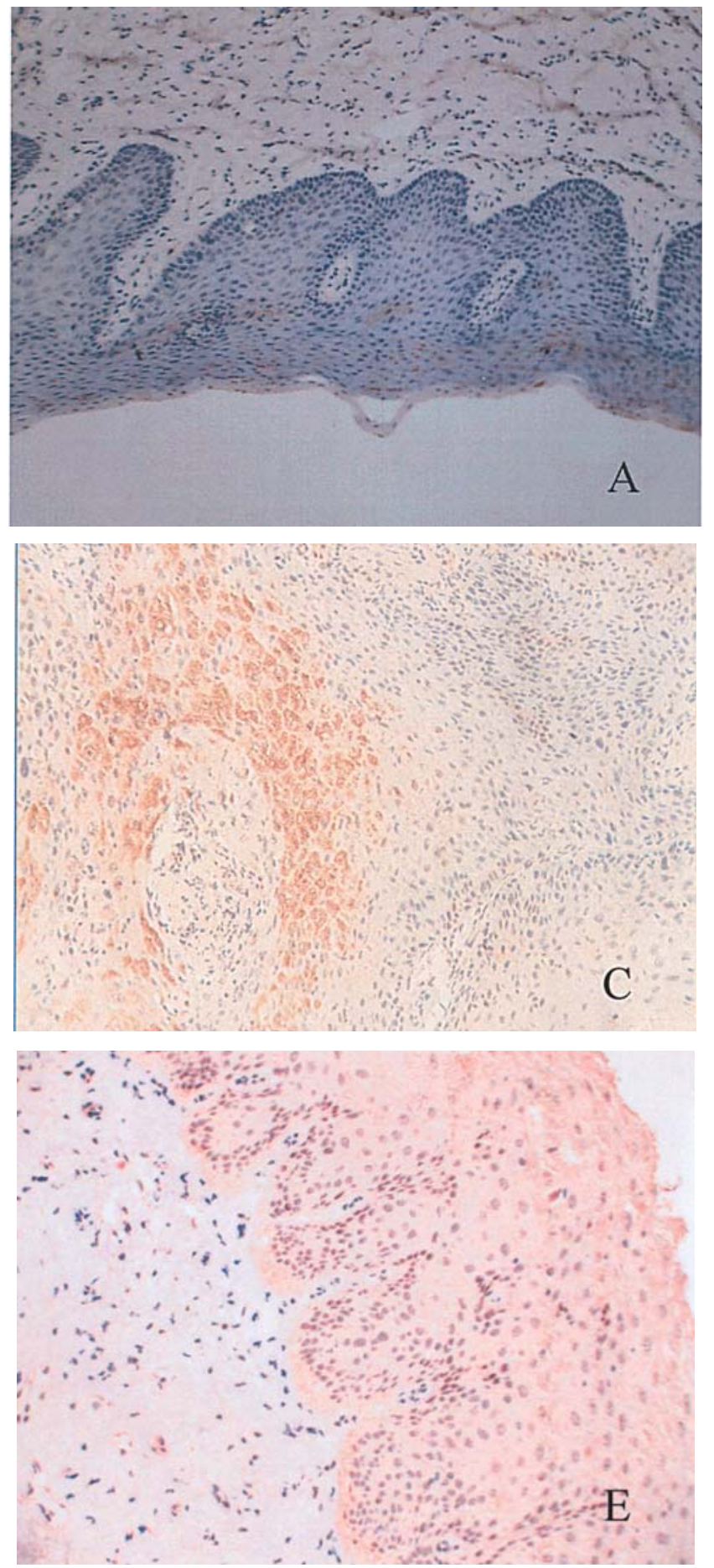
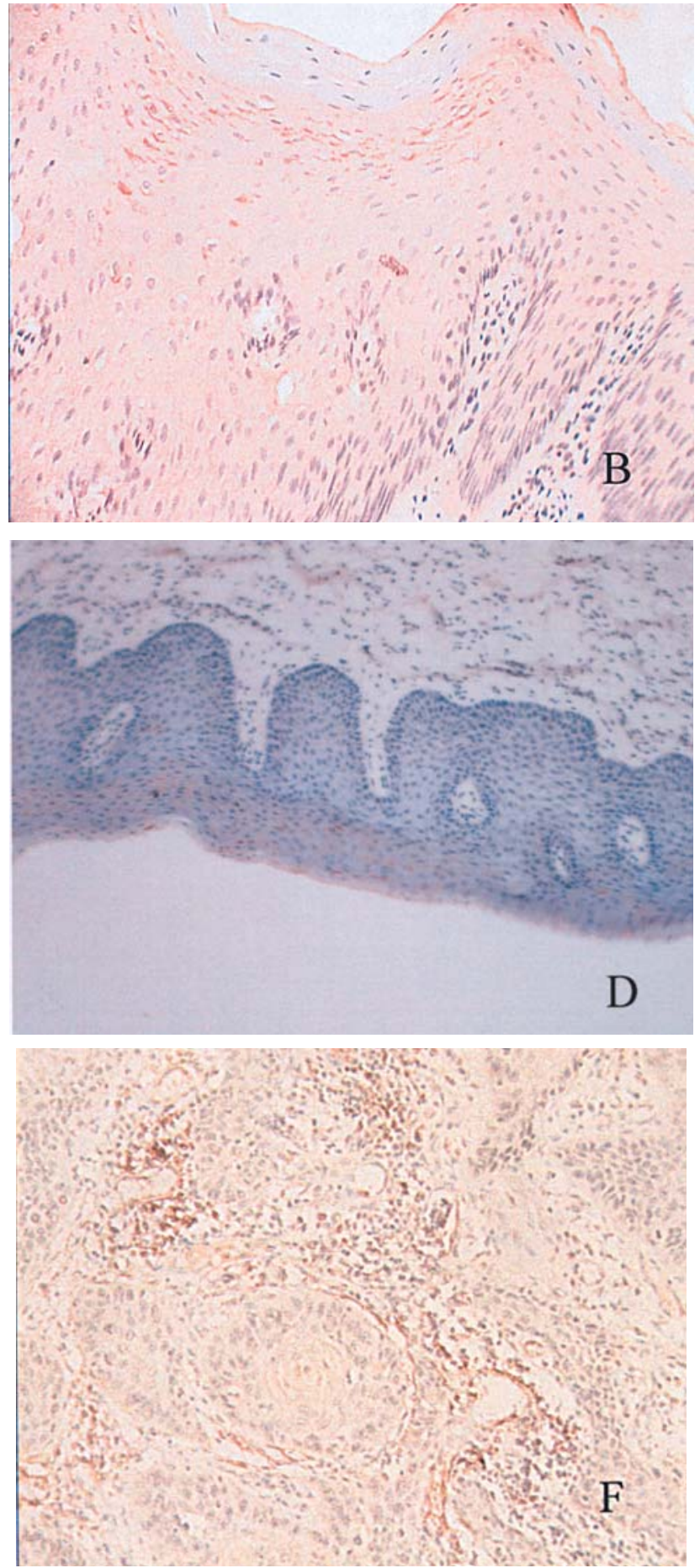

Figure 1. Immunohistochemical detection of COX-2 and E2F-1 proteins in normal oral epithelium, dysplasia and SCC (original magnification, x200). (A) COX-2 expression in normal epithelium; (B) COX-2 expression in oral dysplasia; (C) COX-2 expression in oral SCC; (D) E2F-1 expression in normal epithelium; (E) E2F-1 expression in oral dysplasia; and (F) E2F-1 expression in oral SCC.

nylidene difluoride membrane. After 1-h incubation in blocking solution (5\% non-fat dry milk and $0.1 \%$ Tween-20 in PBS), the membrane was blotted with an antibody against COX-2, E2F-1, pRb, bcl-2, or caspase-3 (all were from Santa Cruz Biotechnology), or a monoclonal anti- $\beta$-actin antibody (Boster, Wuhan, P.R. China) overnight at $4^{\circ} \mathrm{C}$. After being washed with PBS-T, the blots were incubated with peroxidase-labeled secondary antibodies (Boster) for $1 \mathrm{~h}$ at $37^{\circ} \mathrm{C}$. The specific bands were detected by using an enhanced chemiluminescence system (Pierce, IL, USA). The intensity of protein bands was detected by densitometric scanning and reported in band intensity units. The relative abundance of each target was normalized by $ß$-actin.

$P G E_{2}$ measurement. $\mathrm{PGE}_{2}$ levels in the cells before and after treatment with NS398 were assayed in the conditioned media previously frozen at $-70^{\circ} \mathrm{C}$ by using a $\mathrm{PGE}_{2}\left(\mathrm{I}^{125}\right) \mathrm{RIA}$ kit (Suzhou University, Suzhou, P.R. China) according to the manufacturer's instructions. The levels of $\mathrm{PGE}_{2}$ were then normalized by protein concentration. 
Table I. Labeling indices of E2F-1 and COX-2 in oral normal epithelium, dysplasia and oral squamous cell carcinoma.

\begin{tabular}{lccc}
\hline & Cases & COX-2 & E2F-1 \\
\hline Normal & 9 & $2.22 \pm 0.70$ & $3.78 \pm 1.53$ \\
Dysplasia & 38 & $38.05 \pm 2.59^{\mathrm{a}}$ & $38.03 \pm 2.20^{\mathrm{a}}$ \\
$\quad$ Mild & 11 & $30.00 \pm 3.86^{\mathrm{a}}$ & $27.55 \pm 1.88^{\mathrm{a}}$ \\
$\quad$ Moderate & 14 & $35.21 \pm 3.72^{\mathrm{a}}$ & $36.21 \pm 2.75^{\mathrm{a}}$ \\
Severe & 13 & $43.92 \pm 4.51^{\mathrm{a}}$ & $48.85 \pm 3.81^{\mathrm{a}}$ \\
SCC & 54 & $44.17 \pm 3.62^{\mathrm{a}}$ & $36.09 \pm 2.26^{\mathrm{a}}$ \\
$\quad$ Well & 24 & $48.13 \pm 5.82^{\mathrm{a}}$ & $43.04 \pm 3.57^{\mathrm{a}}$ \\
$\quad$ Moderate & 22 & $44.82 \pm 5.87^{\mathrm{a}}$ & $33.23 \pm 3.05^{\mathrm{a}, \mathrm{b}}$ \\
Poorly & 8 & $35.50 \pm 4.43^{\mathrm{a}}$ & $23.13 \pm 3.25^{\mathrm{a}, \mathrm{b}}$ \\
\hline
\end{tabular}

Mean \pm SD. ${ }^{a} \mathrm{p}<0.01$, compared to normal epithelium; ${ }^{b} \mathrm{p}<0.05$ compared to dysplastic lesions.

Statistical analysis. The experimental data were presented as means \pm SD. Statistical analyses included use of a 2-tailed Student's t-test or one-way analysis of variance (ANOVA). The correlation between E2F-1 and COX-2 was assessed by using Spearman's correlation coefficient test. Statistical significance was set at $\mathrm{p} \leq 0.05$.

\section{Results}

Expression of COX-2 and E2F-1 in normal oral mucosae, dysplasia and oral SCC. Positive immunostaining of COX-2 was seen in the cytoplasm of the epithelial cells and the staining pattern was dot-like. COX-2 was weakly expressed in the basal layer of the normal epithelium, but significantly increased in the dysplastic and carcinoma cells (Fig. 1A-C). In particular, 28 of 38 samples $(73.7 \%)$ of dysplastic lesions and 44 of $54(81.5 \%)$ of oral SCC showed positive cytoplasmic staining of COX-2 protein. In oral SCC, the peripheral portion of tumor nests expressed more COX-2 protein than the center of tumor nests. Overall, the mean labeling indices (LI) of COX-2 were $2.22 \pm 0.70$ in normal oral epithelia, $38.05 \pm 2.59$ in the dysplastic lesions, and $44.17 \pm 3.62$ in oral SCC (Table I). The difference was statistically significant between the normal and oral SCC $(\mathrm{p}<0.01)$ and between the normal and dysplastic tissues $(\mathrm{p}<0.01)$. The severe dysplasia lesions and the well differentiated tumors tended to have higher COX-2 expression; however, there was no correlation found between the LIs and the histological grades.

In contrast, the immunoreactivity of E2F-1 was found in the nuclei of the epithelia, although in some cases there was some staining in the cytoplasm (Fig. 1D-F). The mean LIs of E2F-1 for normal epithelia, dysplasia and SCC were $3.78 \pm 1.53,38.03 \pm 2.20$ and $36.09 \pm 2.26$, respectively. The LIs in moderate and severe dysplastic lesions were significantly higher than mild lesions in oral dysplasia $(\mathrm{p}<0.05)$, while in oral SCC the LIs of well differentiated tumors were signi-

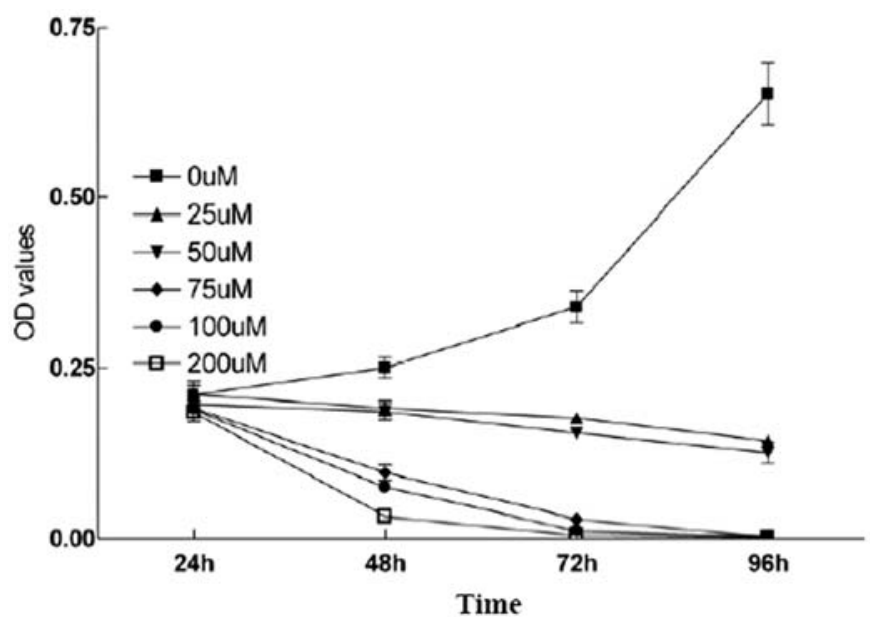

Figure 2. Inhibitory effect of NS398 on proliferation of oral SCC cells Tca8113 cells were cultured in RPMI-1640 medium containing NS398 at concentrations of $0,25,50,75,100$, or $200 \mu \mathrm{M}$ for up to $96 \mathrm{~h}$. Cell viability was measured by MTT assay and the optical density (OD) values were determined. The experiments were in triplicates and repeated three times with similar results.

ficantly higher than the moderate and poorly differentiated cancers $(\mathrm{p}<0.05)$.

Furthermore, 28 samples $(73.7 \%)$ of dysplasia and 41 samples $(75.9 \%)$ of oral SCC expressed high levels of both E2F-1 and COX-2 proteins ( $\mathrm{p}<0.01$, by Spearman's coefficient test, $\mathrm{r}=0.67$ ).

NS398 inhibition of tumor cell proliferation. MTT assay showed that NS398 significantly reduced viability of Tca8113 cells in a dose- and time-dependent manner (Fig. 2). After treatment with $50 \mu \mathrm{M}$ of NS398, the cell viability was reduced to $29.7,54.7$ and $81.51 \%$ after 48 , 72 and 96-h culture, respectively. At $100 \mu \mathrm{M}$ of NS398, the tumor cells were almost unviable.

NS398 induction of apoptosis in Tca8113 cells. To determine whether the reduced cell viability by NS398 in Tca8113 cell line was due to induction of apoptosis, we performed TUNEL assay. Fig. 3 shows that NS398 did induce these cells to undergo apoptosis. Western blot analysis showed that caspase-3 expression was induced, but bcl-2 expression had no change (Fig. 4). Furthermore, data from DNA histograms of a flow cytometric analysis showed a reduced number of cells in the $\mathrm{S}$ and $\mathrm{G} 2-\mathrm{M}$ phases, but accumulation in $\mathrm{G} 1$ phase after the tumor cells were treated with $50 \mu \mathrm{M}$ of NS398 for different periods of time (Fig. 3).

NS398 inhibition of $P G E_{2}$ production. After treatment with NS398, $\mathrm{PGE}_{2}$ levels were significantly reduced compared to the controls for the duration of treatment, demonstrating an inverse relationship between $\mathrm{PGE}_{2}$ production and duration of treatment, i.e., $\mathrm{PGE}_{2}$ concentrations ( $\mathrm{pg} / \mathrm{mg}$ protein) in the conditioned media were 26.56 at $6 \mathrm{~h}, 16.61$ at $12 \mathrm{~h}, 10.42$ at $24 \mathrm{~h}, 2.07$ at $48 \mathrm{~h}$ and 0.98 at 72-h treatment (Fig. 5).

Effect of NS398 on gene expression in Tca8113 cells. We next analyzed gene expression after NS398 treatment. We 
A

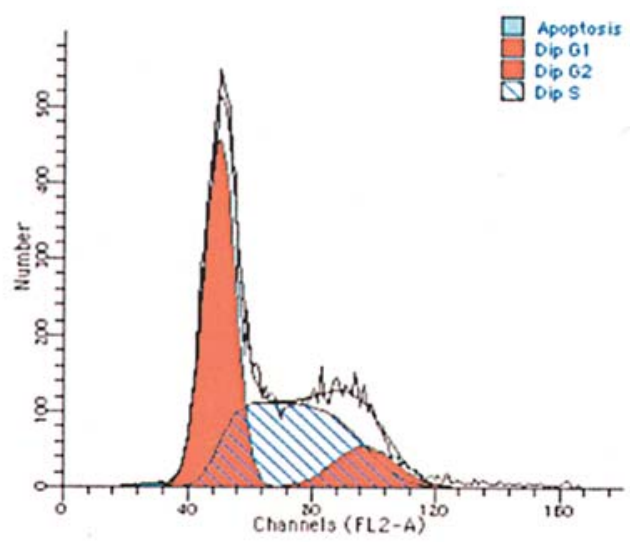

$\mathrm{Oh}$

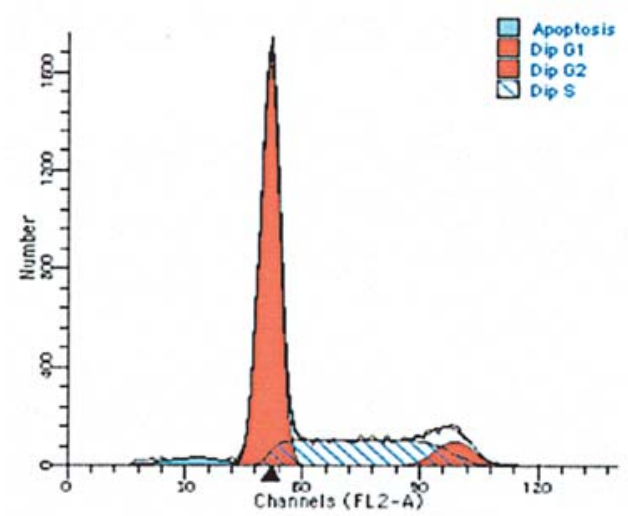

$12 \mathrm{~h}$

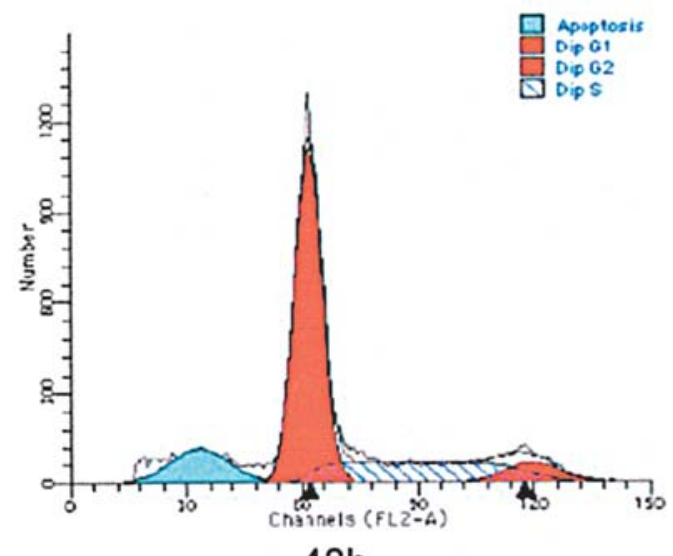

$48 \mathrm{~h}$

B

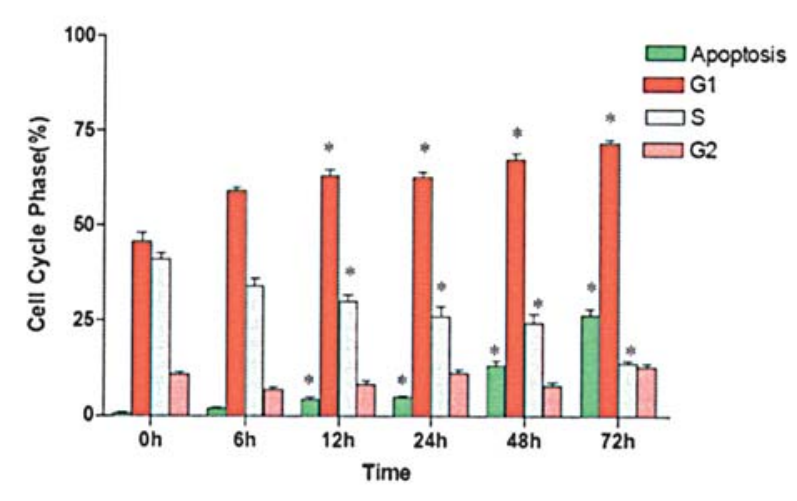

found that NS398 treatment inhibited COX-2 expression in Tca8113 cells compared to the control $(\mathrm{p}<0.01)$ (Fig. 4).

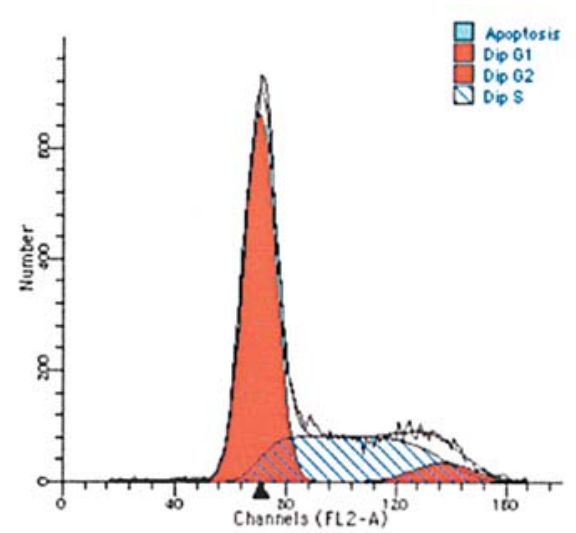

$6 \mathrm{~h}$

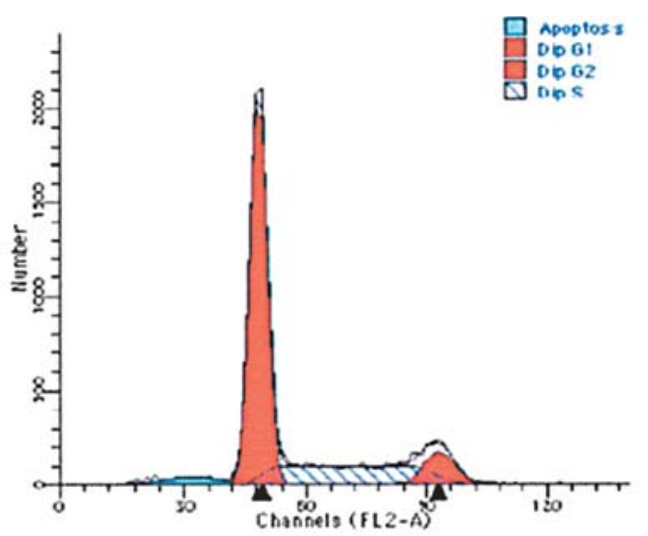

$24 \mathrm{~h}$

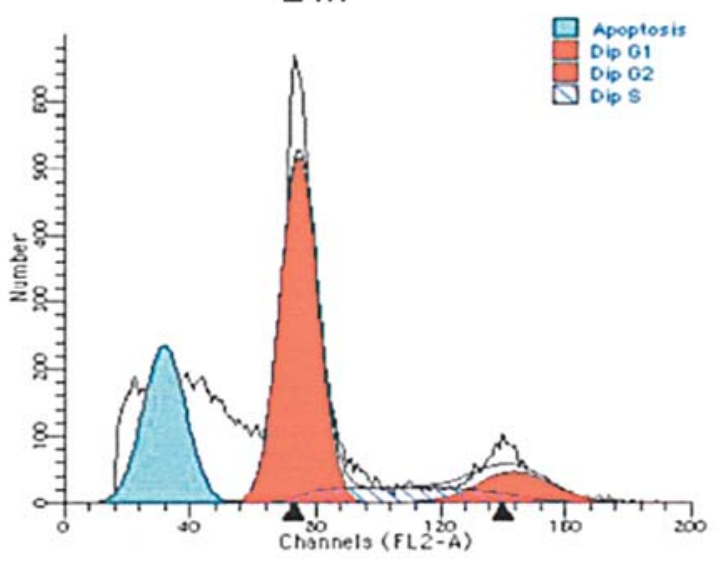

$72 \mathrm{~h}$

Figure 3. Effect of NS398 on cell cycle arrest and apoptosis in oral squamous cell cancer cell line after treated with $50 \mu \mathrm{M}$ of NS398 for up to $72 \mathrm{~h}$. The distribution of cell cycles (A) and apoptosis rate (B) was measured by flow cytometry (see details in Materials and methods).

Meanwhile, expression of pRb and E2F-1 proteins was also suppressed by NS398 treatment in Tca8113 cells (Fig. 4).

\section{Discussion}

In the present study, we analyzed expression of COX-2 and E2F-1 proteins in tissue specimens that represent the multiple stages of oral carcinogenesis - from normal and dysplasia to SCC. We found a significant increase in COX-2 and E2F-1 expression in oral dysplasia and SCC. We then performed a series of experiments to assess whether inhibition of COX-2 


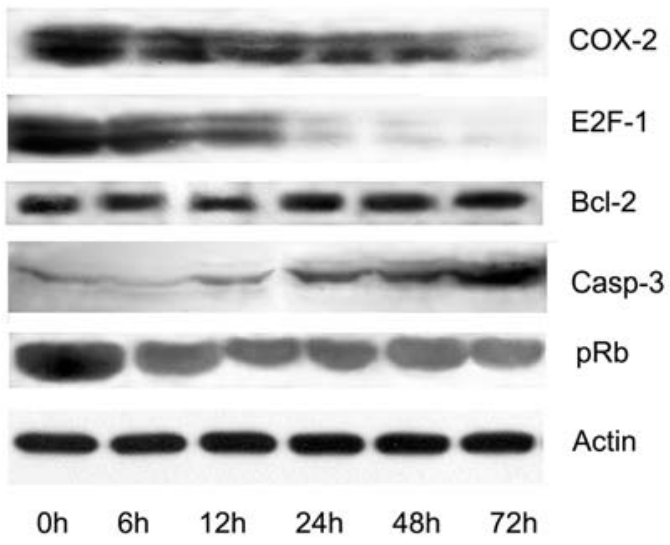

Figure 4. Western blot analysis of gene expression. Tca8113 cells were cultured in RPMI-1640 medium and treated with $50 \mu \mathrm{M}$ of NS398 for different periods of time. The total cellular protein was isolated and subjected to Western blot analyses of different gene expression. Quantified densities of bands were expressed as ratios to the densities of the corresponding $B$-actin. The data were expressed as mean $\pm \mathrm{SD}$. The experiment was repeated once with similar data.

could be used to control oral cancer. We found that NS398 significantly inhibited viability of oral SCC cells and induced them to undergo apoptosis, which was accomplished through induction of caspase- 3 activation and cell cycle arrest at G1 phase. NS398 also suppressed expression of E2F-1 and $\mathrm{pRb}$, but not Bcl-2. The results of this study indicate that suppression of COX-2 enzymatic activity was able to inhibit E2F-1 expression and Rb phosphorylation, which may have potential in the control of oral SCC in future clinical practice.

A number of studies have shown an association between COX-2 overexpression and anti-apoptosis features in different cancer cells. For example, Tsujii and DuBois (25) first showed that transfection of the COX-2 gene into rat intestinal epithelial cells reduced the susceptibility to apoptosis and upregulated the expression of anti-apoptotic Bcl-2 protein. Similar results were observed in human colon cancer cells (26). Terakado et al found that the level of COX-2 expression correlated inversely with increased radiation sensitivity and celecoxib, a selective COX-2 inhibitor, enhanced the radiation response in oral SCC cell line (27). Previous studies had shown that NS398 could suppress growth and induce apoptosis in a number of different cancer cell lines (9,28-30), although a study by Helena et al reported no significant apoptosis in the response of oral SCC cell lines to NS398 treatment except for G0/G1 cell cycle arrest (12). In the current study, we demonstrated that caspase-3 expression was enhanced after NS398 treatment, but no change in bcl-2 levels was found. This indicates that NS398 induction of caspase- 3 activation results in induction of apoptosis, but is independent of bcl-2 reduction.

It has been reported that $>90 \%$ of oral cancers had at least one abnormality that affects Rb, cyclin D1, or p16, which suggests that cell cycle regulation pathways may be useful targets for control of oral carcinogenesis (31). After activation by cyclin D1, CDK4 or CDK6 will phosphorylate the $\mathrm{Rb}$ protein, leading to its functional inactivation and release of transcription factors necessary for entry into $S$ phase and cell cycle progression $(32,33)$. In a recent study

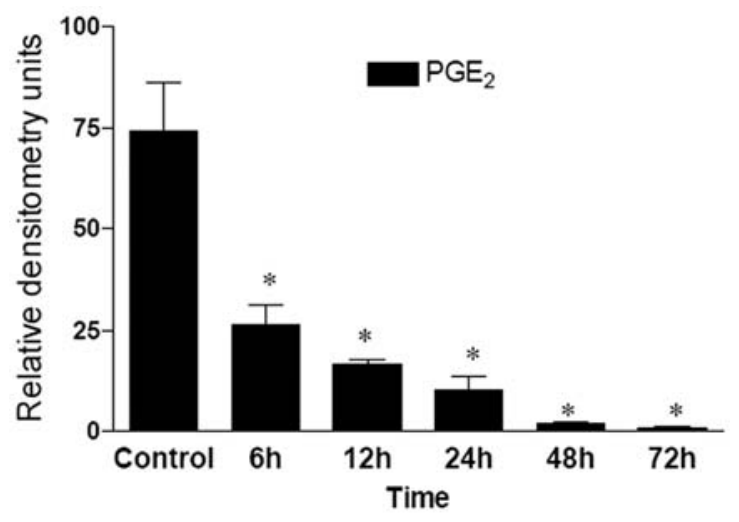

Figure. 5. Suppression of $\mathrm{PGE}_{2}$ production by NS398 treatment in oral SCC cells. Tca8113 cells were cultured in RPMI-1640 medium and treated with $50 \mu \mathrm{M}$ of NS398 for up to $72 \mathrm{~h}$. The conditioned growth medium was used to measure $\mathrm{PGE}_{2}$ levels by using a $\mathrm{PGE}_{2}$ kit (see the Materials and methods). ${ }^{*} \mathrm{p}<0.01$ vs. control.

by Crawford et al (34), silencing of p16 $6^{\mathrm{INK} 4 \mathrm{~A}}$ gene expression through promoter hypermethylation resulted in increased COX-2 levels and elevated $\mathrm{PGE}_{2}$ in mammary epithelial cells. The increased COX-2 expression contributed to increased angiogenic activity and invasiveness. However, NS398 can reduce cell survival and induce apoptosis of mammary epithelial cells (34). Our current data demonstrated that $50 \mu \mathrm{M}$ of NS398 inhibited growth of Tca8113 cells in a dose- and time-dependent manner and induces apoptosis. NS398 was able to reduce E2F-1 expression and inhibit Rb phosphorylation. Indeed, our ex vivo data also showed an association between COX-2 and E2F-1 expression, i.e., high levels of E2F-1 expression were associated with overexpression of COX-2 protein in oral dysplastic and tumor tissues.

Previous studies have reported that cell cycle arrest at G1 phase was induced by different NSAIDs $(35,36)$. Our data also support the NS398-induced cell cycle arrest at G1 phase. Bock et al have reported that celecoxib toxicity is $\mathrm{S}$ phase specific and that inhibition of nuclear E2F-1 function is the possible mechanism (20). Our study showed that NS398 suppressed E2F-1 expression and Rb phosphorylation in an oral SCC cell line.

Development of oral SCC, like all other cancers, involves multiple genetic alterations such as oncogene activation and tumor-suppressor gene dysfunction $(1,37)$. To date, a large body of knowledge has been generated regarding molecular alterations associated with oral carcinogenesis. Molecular biology studies of oral cancer have revealed frequent genetic abnormalities in oral SCC. These alterations include aberrant cell cycle control, cell signaling, cellular enzymes, growth factor receptors, and nuclear receptors (such as p53, p16, cyclin D1, EGFR, E-cadherin, COX-2 and RAR- 3$)(1,37,38)$. The knowledge generated from these studies has begun to coalesce into an improved understanding of oral cancer for early detection, prevention and treatment. Targeting these molecules may help us to discover novel preventive or therapeutic strategies. Indeed, use of NSAIDs has been clinically shown to prevent head and neck cancer. This study further supports their use. 
In summary, our data demonstrated that expression of E2F-1 and COX-2 were induced in oral SCC, and their association and downregulation by NS398 may represent a novel target for prevention and treatment of oral SCC.

\section{Acknowledgments}

We like to thank Xiaolin Song and Ping Zhang for the help of preparation of tissue samples. We thank Xiaomeng Song for discussions and experimental help and for reagents. This work was supported in part by social development grant of Technology Agency of Jiangsu province.

\section{References}

1. Johnson N: Oral cancer: world wide problem. FDI World 6: 19-21, 1997.

2. Moore SR, Johnson NW, Pierce AM and Wilson DF: The epidemiology of tongue cancer: a review of global incidence. Oral Dis 6: 75-84, 2000 .

3. Sano H, Kawahito Y, Wilder RL, et al: Expression of cyclooxygenase- 1 and -2 in human colorectal cancer. Cancer Res 55: 3785-3789, 1995.

4. Ristimaki A, Honkanen N, Jankala H, Sipponen P and Harkonen M: Expression of cyclooxygenase-2 in human gastric carcinoma. Cancer Res 57: 1276-1280, 1997.

5. Hwang D, Scollard D, Byrne J and Levine E: Expression of cyclooxygenase- 1 and cyclooxygenase- 2 in human breast cancer. J Natl Cancer Inst 90: 455-460, 1998.

6. Ratnasinghe D, Tangrea J, Roth MJ, et al: Expression of cyclooxygenase-2 in human squamous cell carcinoma of the esophagus: an immunohistochemical survey. Anticancer Res 19: 171-174, 1999.

7. Hida T, Yatabe Y, Achiwa H, et al: Increased expression of cyclooxygenase-2 occurs frequently in human lung cancers, specifically in adenocarcinoma. Cancer Res 58: 3761-3764, 1998.

8. Okami J, Yamamoto H, Fujiwara Y, et al: Overexpression of cyclooxygenase-2 in carcinoma of the pancreas. Clin Cancer Res 5: 2018-2024, 1999.

9. Joki T, Heese O, Nikas DC, et al: Expression of cyclooxygenase $2(\mathrm{COX}-2)$ in human glioma and in vitro inhibition by a specific COX-2 inhibitor, NS398. Cancer Res 60: 4926-4931, 2000.

10. Nishimura N, Urade M, Hashitani S, Noguchi K, Manno Y, Takaoka K and Sakurai K: Increased expression of cyclooxygenase (COX)-2 in DMBA-induced hamster cheek pouch carcinogenesis and chemopreventive effect of a selective COX-2 inhibitor celecoxib. J Oral Pathol Med 33: 614-621, 2004.

11. Wang Z, Fuentes CF and Shapshay SM: Antiangiogenic and chemopreventive activities of celecoxib in oral carcinoma cell. Laryngoscope 112: 839-843, 2002.

12. Helena A, Minter, John W, et al: The cyclooxygenase-2-selective Inhibitor NS398 inhibits proliferation of oral carcinoma cell lines by mechanisms dependent and independent of reduced prostaglandin E2 synthesis. Clin Cancer Res 5: 1885-1897, 2003.

13. Sumitani K, Kamijo R and Toyoshima T: Specific inhibition of cyclooxygenase- 2 results in inhibition of proliferation of oral cancer cell lines via suppression of prostaglandin E2 production. J Oral Pathol Med 30: 41-47, 2001.

14. Grosch S, Tegeder I, Niederberger E, Brautigam L and Geisslinger G: COX-2 independent induction of cell cycle arrest and apoptosis in colon cancer cells by the selective COX-2 inhibitor celecoxib. FASEB J 15: 2742-2744, 2001.

15. Denkert C, Furstenberg A, Daniel PT, et al: Induction of G0/G1 cell cycle arrest in ovarian carcinoma cells by the anti-inflammatory drug NS398, but not by COX-2-specific RNA interference. Oncogene 22: 8653-8661, 2003.

16. Johnson DG, Schwarz JK, Cress WD and Nevins JR: Expression of transcription factor E2F-1 induces quiescent cells to enter $\mathrm{S}$ phase. Nature 365: 349-352, 1993.
17. Slansky JE and Farnham PJ: Introduction to E2F family: protein structure and gene regulation. Curr Top Microbiol Immunol 208: 1-30, 1996.

18. Cam H and Dynlacht BD: Emerging roles for E2F: beyond the G1/S transition and DNA replication. Cancer Cell 3: 311-316, 2003.

19. Davis JN, McCabe MT, Hayward SW, Park JM and Day ML: Disruption of $\mathrm{Rb} / \mathrm{E} 2 \mathrm{~F}$ pathway results in increased cyclooxygenase-2 expression and activity in prostate epithelial cells. Cancer Res 65: 3633-3642, 2005.

20. Bock JM, Menon SG, Sinclair LL, Bedford NS, Goswami PC, Domann FE and Trask DK: Celecoxib toxicity is cell cycle phase specific. Cancer Res 67: 3801-3808, 2007.

21. Kusume T, Tsuda H, Kawabata M, Inoue T, Umesaki N, Suzuki T and Yamamoto K: The p16-cyclin D1/cdk-4-pRb pathway and clinical outcome in epithelial ovarian cancer. Clin Cancer Res 5: 4152-4157, 1999.

22. Ralhan R, Mathew R, Arora S, Bahl R, Shukla NK and Mathur M: Frequent alterations in the expression of tumor suppressor genes $\mathrm{p} 16 \mathrm{INK} 4 \mathrm{a}$ and $\mathrm{pRb}$ in esophageal squamous cell carcinoma in the Indian population. J Cancer Res Clin Oncol 126: 655-660, 2000 .

23. Kwong RA, Nguyen TV, Bova RJ, et al: Overexpression of E2F-1 is associated with increased disease-free survival in squamous cell carcinoma of the anterior tongue. Clin Cancer Res 9: 3705-3711, 2003

24. Ebihara Y, Miyamoto M, Shichinohe T, et al: Overexpression of E2F-1 in esophageal squamous cell carcinoma correlates with tumor progression. Dis Esophagus 17: 150-154, 2004.

25. Tsujii $\mathrm{M}$ and DuBois RN: Alterations in cellular adhesion and apoptosis in epithelial cells overexpressing prostaglandin endoperoxide synthase-2. Cell 83: 493-501, 1995.

26. Sun Y, Tang XM, Half E, Kuo MT and Sinicrope FA: Cyclooxygenase-2 overexpression reduces apoptotic susceptibility by inhibiting the cytochrome c-dependent apoptotic pathway in human colon cancer cells. Cancer Res 62: 6323-6328, 2002.

27. Terakado N, Shintani S, Yano J, Chunnan L, Mihara M, Nakashiro K and Hamakawa H: Overexpression of cyclooxygenase-2 is associated with radioresistance in oral squamous cell carcinoma. Oral Oncol 40: 383-389, 2004.

28. Elder DJ, Halton DE, Hague A and Paraskeva C: Induction of apoptotic cell death in human colorectal carcinoma cell lines by a cyclooxygenase-2 (COX-2) selective non-steroidal antiinflammatory drug: independence from COX-2 protein expression. Clin Cancer Res 3: 1679-1683, 1997.

29. Liu XH, Yao S, Kirschenbaum A and Levine AC: NS398, a selective cyclooxygenase-2 inhibitor, induces apoptosis and downregulates bcl-2 expression in LNCcaP cells. Cancer Res 58: 4245-4249, 1998.

30. Li M, Wu X and Xu XC: Induction of apoptosis by cyclooxygenase-2 inhibitor NS398 through a cytochrome C-dependent pathway in esophageal cancer cells. Int J Cancer 93: 218-223, 2001.

31. Okami K, Reed AL, Cairns P, et al: Cyclin D1 amplification is independent of p16 inactivation in head and neck squamous cell carcinoma. Oncogene 18: 3541-3545, 1999.

32. Weinberg RA: The retinoblastoma protein and cell cycle control. Cell 81: 323-330, 1995.

33. King KL and Cidlowski JA: Cell cycle and apoptosis: common pathways to life and death. J Cell Biochem 58: 175-180, 1995.

34. Crawford YG, Gauthier ML, Joubel A, Mantei K, Kozakiewicz K, Afshari CA and Tlsty TD: Histologically normal human mammary epithelia with silenced p16(INK4a) overexpress COX-2, promoting a premalignant program. Cancer Cell 5: 263-273, 2004.

35. Buecher B, Broquet A, Bouancheau D, et al: Molecular mechanisms involved in the antiproliferative effect of two COX-2 inhibitors, nimesulide and NS398, on colorectal cancer cell lines. Dig Liver Dis 35: 557-565, 2003.

36. Li J, Chen X, Dong X, Xu Z, Jiang H and Sun X: Specific COX-2 inhibitor, meloxicam, suppresses proliferation and induces apoptosis in human HepG2 hepatocellular carcinoma cells. J Gastroenterol Hepatol 21: 1814-1820, 2006.

37. Lippman SM, Sudbo J and Hong WK: Oral cancer prevention and the evolution of molecular-targeted drug development. J Clin Oncol 23: 346-356, 2005.

38. Xu XC, Ro JY, Lee JS, Shin DM, Hong WK and Lotan R: Differential expression of nuclear retinoid receptors in normal premalignant and malignant head and neck tissues. Cancer Res 54: 3580-3587, 1994. 